\title{
Mycology at The New York Botanical Garden, $1895-1995$
}

\author{
Clatrk T. Rogerson and Gary J. Samuels
}

\begin{abstract}
Rogerson, C. T. (The New York Botanical Garden, Bronx, NY 10458, U.S.A.) and G. J. Samuels (USDA, Agricultural Research Service, Systematic Botany and Mycology Laboratory, Beltsville, MD 20705, U.S.A.) Mycology at The New York Botanical Garden, 18951995. Brittonia 48:389-398. 1996.-A review of the first 100 years of studies on fungi (including lichens) at The New York Botanical Garden is presented.
\end{abstract}

Studies on fungi have been part of The New York Botanical Garden's research program from the very beginning of the Garden's existence. Taxonomic and floristic aspects have always been emphasized, and the accumulation of collections for the herbarium as well as the building up of a library have always been paramount. Continued emphasis on systematic studies over the past 100 years has created one of the leading facilities for research on fungi. Laboratory and experimental activities in fungal physiology, biochemistry, and genetics, as well as in the practical aspects of plant pathology, have all been important elements in the mycological program at the Garden. Following is a brief review of the Garden's mycologists and their research.

\section{The Beginning}

In 1896 , as a first step in establishing a herbarium of fungus specimens, parts of the collections of J. B. Ellis and his colleague B. M. Everhart were purchased: 15,000 collections including more than 3000 type specimens. In 1900 the rest of the collection was acquired, bringing the total Ellis collection to 80,000 items and the entire mycological collection of the Garden to about 100,000 specimens.

Ellis was a farmer in New Jersey who never held an academic or curatorial position. Over a period of 40 years, beginning with his first publication in 1874, he became the American authority of microfungi. To his own collections he added specimens sent to him from all parts of North America as well as from Europe and the rest of the Americas. He was one of the founders of the Journal of Mycology (vols. 1-14, 18851908) and was a frequent contributor to its pages. Ellis and Everhart's major work was North American Pyrenomyceles (1892); the Garden, because it has their collections, became the center for study on this group of fungi. Alone and with Everhart, Ellis introduced the fungi of North America to the rest of the world through three works of fungi exsiccati: Fungi Nova-Caesareenses (1877), North American Fungi (18781898), and Fungi Columbiana (1893-1899).

The first mycologist to join the Garden's staff was F. S. Earle (1856-1929; for a biography, see Chardon, 1929), Assistant Curator of Fungi from 1901 to 1904 . Earle specialized in fungi associated with diseases of flowering plants; he collected in Alabama, Illinois, New Mexico, Texas, Cuba, Jamaica, and Puerto Rico. While at the Garden, Earle accelerated the arrangement of the Ellis collections. Although he specialized in agarics, he also covered various groups of ascomycetes and imperfect fungi. When he left the Garden and went to Cuba in 1904, he became the leading authority on all aspects of sugarcane culture. His large collection of fungi was purchased by the Garden.

L. M. Underwood's (1853-1907) early interests included morphological and taxonomical studies on fungi. He made many local collections and these, together with collections from Indiana, Jamaica, and Puerto Rico $(17,000)$, were purchased and added to the Garden's herbarium after his death. (For a fuller account of Underwood's career at the Garden, see Mickel, this volume.)

\section{The Murrill Years: 1904-1924}

William A. Murrill (1869-1957; for a biography, see Weber, 1961) can arguably be called 
the first great mycological curator at The New York Botanical Garden because of the number of his scientific publications and their continuing impact on fungal taxonomy and also because of the people whom he attracted to the Garden.

Murrill was a Virginian who obtained his Ph.D. at Cornell University in 1897, working under G. F. Atkinson, the leading North American authority on the taxonomy of mushrooms and similar fungi (Basidiomycetes). For the several years that Murrill taught at DeWitt Clinton High School in New York City, he expanded his mycological expertise through close contact with L. M. Underwood, who was at Columbia University. Murrill also began to use the Garden's herbarium and library, and in 1904 he replaced Earle as Assistant Curator, eventually becoming a Curator (1919-1924). At one point he supervised the Garden's Public Education Program, and at another he served as the Garden's Assistant Director (1909-1919).

Murrill's greatest scientific contributions were in study of the Agaricales and Polyporaceae. His classification of the Polyporaceae, under the American Code of Botanical Nomenclature, resulted in the recognition of many name changes and new taxa. Only later did people recognize how advanced the Murrill system was; during his years of greatest activity he was much criticized, sometimes acrimoniously, as a "splitter." $\mathrm{He}$ was a prodigious collector and obtained specimens from the eastern, southern, and western United States, Mexico, the West Indies, and southward to Argentina. He visited Europe to study type specimens in herbaria and to obtain specimens to compare with those in America.

From 1885 to 1908 , the principal venue for publication of mycological information, scientific findings on fungi, and discussion of mycology for North America was the Journal of Mycology. Founded and edited by W. A. Kellerman of Ohio State University, the journal ceased publication with Kellerman's death from malaria while on expedition in Guatemala in 1908. At Murrill's instigation, the journal Mycologia was founded by the Garden as a continuation of the Journal of Mycology, and Murrill edited the new journal for 16 years. In 1932 an agreement between the Garden and the newly established Mycological Society of America made Mycologia the official scientific journal of the Society. Currently, editorial aspects are handled by the Society and all financial aspects are handled by the Garden. $M y$ - cologia has become a leading publication on fungi throughout the world and is currently (in 1996) in its 88th volume.

Murrill realized that color reproductions of mushrooms were vital for identification. From 1908 to 1913, he and artist E. C. Volkert experimented with methods of illustrating fleshy fungi in color. At first they tried to use color photographs, but the various papers available for printing at that time proved to be useless. Concentration was then given to watercolor paintings from fresh collections. A printing method was devised using a halftone, four-color process, and paintings of 167 species of fungi were reproduced in Mycologia. Later, artist Mary E. Eaton contributed some 225 paintings, mostly of local mushrooms, and some of these were reproduced in Mycologia.

In 1905 an unknown disease resulted in the death of many American chestnut trees in Bronx Park, where The New York Botanical Garden and Bronx Zoo are located. Murrill studied the disease, isolated and described the causal fungus (Diaporthe parasitica, now Cryphonectria parasitica), and proved by inoculation into healthy plants that the fungus caused the disease. Subsequently, chestnut blight virtually wiped out the American chestnut in North America and changed forever not only the composition of the northeastern hardwood forests but also the lives of the people who depended on the American chestnut for their livelihoods. The chestnut blight and the devastation that it wrought have become both a model for scientific study and a cautionary tale about the introduction of pathogens into the country.

Murrill published 510 papers, mostly on fungi. Included are floristic revisions on polypores, boletes, and agarics (Basidiomycetes) for North America (North American Flora volumes 9 and 10). His collections totalled more than 70,000 , including 1796 types. He left the Garden in 1924, complaining that the administrative burden left him no time for scientific research and that, as an administrator, he was required to think for other people as well as for himself. He eventually returned to the vicinity of his childhood home in Virginia, where he lived in a cottage that he built. During this time he spent his winters in the Gainesville region of Florida, where he was discovered in the 1940 s by G. F. Weber, of the University of Florida, playing classical piano in the recreation hall of a tourist 
court. He was persuaded to return to mycology, and he again began publishing on higher fungi (1940s to 1957) from the herbarium of the University of Florida. In this second phase of Murrill's career he reported more than 600 species of agarics plus 50 or more hydnums and polypores from Florida. He died at the age of 88 in 1957, in Gainesville.

Gertrude S. Burlingham (1872-1952; for a biography, see Seaver, 1953) obtained her doctoral degree in botany at Columbia University in 1908 and spent her professional life as a teacher of biology in Brooklyn high schools. Her contacts with Murrill and the Garden fostered her interest in mushrooms; she became the North American specialist on two of the most diverse genera, Lactarius and Russula. She published more than 20 papers on the genera, including treatments in the Garden's North American Flora. She collected extensively in the eastern United States (particularly in New England, New York, and Florida) and on the West Coast, as well as in Europe (especially Sweden). Her herbarium, comprising more than 10,000 collections, and her library were willed to the Garden. In addition, funds from her estate were allocated to the Garden to establish a fellowship that was to support a student of mycology. Income from this fund usually has been sufficient to support a graduate student who needs to use the facilities (herbarium, library, laboratory) at the Garden or to do fieldwork for a period of 2-4 months. From 1956 to 1994, 27 fellowships have been awarded. Several of the fellowship recipients are now leading mycologists.

In 1905 the Garden purchased the personal herbarium, original drawings (including color paintings), notes, and other illustrations from George Massee, an English mycologist who worked at Kew. Many of the illustrations had been prepared for a monograph (unpublished) of Discomycetes. More than 3500 collections of discomycetes were received.

Howard J. Banker (1866-1940; for a biography, see Barnhart, 1941), having received his $\mathrm{Ph}$.D. from Columbia University in 1906, became acquainted with the Garden and developed an interest in fungi, particularly the Hydnaceae (Basidiomycetes). He was Professor of Botany at DePauw University until 1914. In 1914 he joined the Eugenics Record Office of the Carnegie Institution at Cold Spring Harbor, Long Island, where he worked on human genetics and genealogy until his retirement. He then concentrated on a taxonomic treatment of North American members of the Hydnaceae, but he died before it was completed. His herbarium, containing about 5000 collections, was presented to the Garden in 1941 by his widow.

\section{The Seaver Years: 1912-1948}

Fred J. Seaver (1877-1970; for biography, see Rogerson, 1973) obtained his Ph.D. in mycology at the University of Iowa. After a brief period as a mycologist with the North Dakota Experiment Station, he became a Fellow in the joint Columbia University-New York Botanical Garden program (1906). Three years later he joined the Garden's staff as Director of Laboratories (1909-1911), after which he became Curator of Nonflowering Plants (1912-1943) and then Head Curator (1943-1948). His specialty was the cup-fungi (Discomycetes), and his two books about them [North American Cup-Fungi (Operculates) and North American Cup-Fungi (Inoperculates)] became the standard works on the taxonomy of cup-fungi and a stimulus for many future American mycologists to study the group. But his contributions extend over a wider taxonomic and geographic range of fungi. In his 40 years at the Garden he collected fungi in eastern U.S., Colorado, Bermuda, and the West Indies, and he published more than 125 scientific papers. In addition to his seminal publications on the cup-fungi, his monograph of the North American Hypocreales (published in Mycologia in 1909 and 1910) and the mycology of Puerto Rico and the American Virgin Islands (published with Carlos E. Chardon in the Scientific Survey of Puerto Rico and the Virgin Islands (1926) have not been replaced by more recent treatments.

Seaver was editor (1925-1932), editor-inchief (1932-1945), and managing editor (19331947) of Mycologia. He retired from the Garden in 1948 to live in Florida, but he remained active in mycology until at least 1951 , when the second volume of the cup-fungi (Inoperculates) was released. He received the Distinguished Service Award from the Garden in 1955.

Elizabeth E. Morse (1864-1955; for a biography, see Bonar, 1956) was born in Massachusetts and spent around 25 years teaching and supervising art training in and around New York City. In 1926 she was awarded a bachelor's de- 
gree in botany from Wellesley College and moved to California, where she was a guest in the Department of Botany at the University of California, Berkeley, for more than 20 years. While in California, she organized the California Mycological Society and collected widely on the West Coast. Eleven of her papers on western fungi were published in Mycologia. Pleased with Dr. Seaver's help and friendliness toward her studies on fungi, in 1942 she started to send money (as anonymous gifts) to the Garden to be used in any way that Seaver chose. With these funds Seaver had the Garden establish a Mycologia endowment fund, the income from which is to be used to support the publication of $M y$ cologia. She instructed that a set of her collections be deposited at the Garden after her death, which occurred in 1955.

Robert Hagelstein (1870-1945), a resident of Long Island, New York, had an active business career in management of a successful mercantile concern. He adopted microscopy as a hobby, and in middle life he retired from business and, for the next $20+$ years, pursued his studies on diatoms and slime molds (Myxomycetes or Mycetozoa). He was invited by N. L. Britton to participate in the Scientific Survey of Puerto Rico and the Virgin Islands. He made collecting trips primarily for diatom material in 1925, 1928, and 1929; the report on diatoms was published in 1939. At the same time he became fascinated with the slime molds. He began publishing on them in 1927 and after 1935 concentrated on taxonomic and life-history studies of the organisms, mostly from Long Island and eastern Pennsylvania but also from Canada to Florida, Trinidad, and the West Indies. Hagelstein was appointed to the staff as Honorary Curator (1930-1945) of the Myxomycetes. In 1944 he published Mycetozoa of North America, Based upon Specimens in the Herbarium of The New York Botanical Garden. His collections of diatoms and slime molds (over 5000) are among the prizes in the Garden's Cryptogamic Herbarium and were the largest in North America during his time.

William C. Sturgis (1862-1942; for a biography, see Hagelstein, 1944) devoted his professional life to the diseases of field crops and forest trees. Until 1914 he was Dean of the School of Forestry at Colorado College. However, his avocation was slime molds (Myxomycetes), in which he became an early American authority.
His interest in myxomycetes was piqued during a visit to Connecticut; later, during a visit to England, he was a guest in the home of Arthur Lister, the English authority on myxomycetes. He had a long correspondence with Lister and his daughter Gulielma, and received from each specimens of rare and/or new species. Sturgis's valuable collection of approximately $3000 \mathrm{spec}-$ imens, and his correspondence, was purchased by the Garden in 1938. With the accession of the Hagelstein and Sturgis collections, the Myxomycete collection of the Garden comprised more than 10,000 specimens in 1938 .

Donald P. Rogers (b. 1908) followed Seaver as Curator of Cryptogamic Botany (1947-1957). His specialties are taxonomy of the lower Basidiomycetes (Thelephoraceae), fungal floras of Hawaii and the Marshall Islands, history of mycology, and nomenclature. During his 10 years at the Garden, he completely rearranged the fungus collections from the antiquated Engler and Prantl system to a modern system. He served as managing editor of Mycologia during that period and was president of the Mycological Society of America in 1956-1957. In 1958 Dr. Rogers moved to the University of Illinois, where he taught until his retirement. Apart from his groundbreaking and enduring work with the jelly fungi, Dr. Rogers's continuing impact on mycology is seen in the Latin descriptions he occasionally provides for the younger and less classically trained mycologists of today (among which the junior author of this article includes himself).

Sanford M. Zeller (1884-1948; for a biography, see Gilkey, 1949) was plant pathologist at Oregon State University. Early in his career, he became interested - thanks in part to a visit by Murrill to the University of Washington-in the puff-ball fungi and their allies (Gasteromycetes), particularly those that are hypogeous and trufflelike. Since few of these were plant pathogens, he studied them as a hobby, and thus his collections were not part of the holdings of the herbarium at Oregon State. Zeller became the North American authority on Gasteromycetes. After retirement he studied them full time. During his last year, he spent four months at the Garden preparing a treatment of them for publication in North American Flora, but he died before the work was completed. He was able to complete the keys, however, publication of which stands as a major contribution to science. Zeller's col- 
lections of gasteromycetes and his manuscript were obtained by the Garden, giving it one of the world's best and largest collections of the group.

\section{The Rogerson Years: 1958-Present}

Clark T. Rogerson joined the staff as Curator of Cryptogamic Botany in 1958. He obtained his Ph.D. at Cornell University with a major in mycology. He spent eight years at Kansas State University teaching mycology, collecting and identifying fungi of Kansas, and working as mycologist for the Kansas Experiment Station. At Cornell he began monographic and life-history studies of members of the Hypocreales (Ascomycetes), and this has continued to be his major research project at the Garden, though he has studied fungi from all parts of the world, particularly eastern, central, and western United States and those collected by Garden staff collecting in the Neotropics. A project on the fungi of Utah, started more than 60 years ago, has accelerated in recent years. So far, approximately 3000 species of fungi and myxomycetes from Utah have been studied and identified.

Between 1960 and the present, more than 3000 living cultures of fungi collected in the United States, Latin America, and the Caribbean were obtained in cooperation with Gary J. Samuels. Rogerson was managing editor of $M y$ cologia from 1958 to 1989 and was editor-inchief of Mycologia for seven volumes. He edited the Memoirs of The New York Botanical Garden (1963-1988), North American Flora (19631988) and the Flora Neotropica Monographs (1969-1983). He was President of the Mycological Society of America during 1968-1969. In 1979 he received the Special Service Award from the Mycological Society of America in recognition of his service to the society, especially for his influence on the journal Mycologia (1981). He taught courses in mycology in the joint New York Botanical Garden-City University of New York program of graduate studies as well as courses in cryptogamic botany for the Garden's educational programs. In acknowledging his many contributions to the Garden, the Board of Managers honored him with the Garden's Distinguished Service Award in 1984. For many years, Rogerson was the only mycologist in the New York City area capable of identifying mushrooms. Over a 35-year period he gave many lectures on fungi and was involved in the formation of several local amateur mycological societies, such as the New York Mycological Society, the New Jersey Mycological Society, and the Connecticut-Westchester Mycological Association (COMA). This service to amateur mycology in America was recognized in 1980 with a special award from the North American Mycological Association.

Kent P. Dumont joined the staff as Associate Curator of Fungi (1969-1977) and became Curator (1977-1987). He obtained his Ph.D. at Cornell University, where he began a worldwide monograph of a group of cup-fungi (Sclerotiniaceae-Ascomycetes). Since many of the species occurred in tropical regions, Dumont embarked on expeditions, supported by NSF funds, to the Neotropics, including Puerto Rico, Jamaica, Panama, Colombia, Venezuela, Ecuador, Bolivia, and Brazil. He made an effort to collect all fungi, sending to various specialists the specimens outside his specialty. The Garden's collections of neotropical fungi were greatly enriched by these many thousands of collections. Dumont left the Garden and mycology in 1987 to pursue a career in business.

Gary J. Samuels began his association with the Garden with a summer job in 1965, when he worked with Achyla under Alma Barksdale. In 1966, after completing a B.Sc. degree in botany at the Pennsylvania State University, he came to the Garden as Rogerson's doctoral student working on systematics of the Hypocreales while enrolled in the Columbia University-New York Botanical Garden graduate program. After completing his study in 1971, he continued work on Nectria with The National Institutes of Health support until early 1973 , when he took up a position as mycologist with the Department of Scientific and Industrial Research in New Zealand. During his time in New Zealand, he joined The New York Botanical Garden's 1977 and 1984 expeditions to the state of Roraima in Brazil for the Projeto Flora Amazonica. In 1984 Samuels collected in Cerro de la Neblina, on the Venezuelan side of the border with Brazil. In 1985 he joined the British Royal Entomological Society expedition for six weeks of fieldwork in North Sulawesi, Indonesia. Specimens of all groups of fungi that were collected during these trips are deposited at the Garden. Samuels returned to the Garden in 1986, where he was supported until late 1989 under successive National 
Science Foundation grants with C. T. Rogerson to work on tropical Hypocreales. During these years, he made the first extensive modern mycological collections in French Guiana (including Mt. Galbao) and Guyana (including Mts. Ayanganna and Wokomung). More than 6000 specimens of all groups of fungi collected in French Guiana and Guyana are deposited at the Garden. In 1989 he took up a position with the U.S. National Fungus Collections (U.S. Department of Agriculture) in Beltsville, Maryland. His continuing collaboration with Rogerson has resulted in several mycological publications and a monograph of the ascomycete genus Hypomyces.

Amy Y. Rossman, currently director of the U.S. National Fungus Collections of the U.S.D.A., was a postdoctoral fellow working on the Hypocreales with Rogerson at the Garden in 1979-1980. She has been a close collaborator in studying the Hypocreales with both Rogerson and Samuels since she was a graduate student at Oregon State University (1969-1974).

Roy E. Halling was appointed to the staff as Assistant Curator of Fungi in 1984 and has been Associate Curator since 1990 . He obtained his $\mathrm{Ph} . \mathrm{D}$. at the University of Massachusetts in 1980 , specializing in a group of mushrooms (Collybia, Basidiomycetes). He has taken over the much needed task of helping colleagues and amateur mycologists in the identification of mushrooms, and he has supervised the rearrangement of Basidiomycetes in the herbarium. $\mathrm{He}$ was managing editor of Mycologia from 1989 to 1996. In 1985 Halling was among the second group of mycologists, and the first agaricologist, to collect on Cerro de la Neblina. He continues his research on the Tricholomataceae and the Boletaceae and has expanded his coverage from eastern and western North America to include much of Latin America. Special projects include floristic studies of Costa Rican and New York state Agaricales; monographic studies of New World species of Collybia, Marasmius, and Marasmiellus; boletes of Colombia and eastern North America; biogeography of Agaricales; and taxonomy and phylogeny of Boletaceae.

Sabine M. Huhndorf joined the staff as Assistant Curator of Fungi in 1990 for 3 years. She obtained her Ph.D. from the University of Illinois, with a specialty in taxonomy and morphology of pyrenomycetous fungi (Ascomy- cetes). Since many unknown or poorly known species of this group occur in the tropics, she joined expeditions to French Guiana, Puerto Rico, and Venezuela to obtain specimens. While at the Garden she rearranged the ascomycetes and participated with Rogerson and Margaret Barr in an accounting of Ellis's pyrenomycetous fungi. After leaving the Garden in 1993, she joined the U.S. Forest Service in Madison, Wisconsin, to work on ascomycetes of Puerto Rico; she is currently working on tropical Ascomycetes at the Field Museum of Natural History in Chicago.

Robert Gordon Wasson (1898-1986), who worked variously as journalist, banker, and financier, became interested in the folklore of mushrooms when he married a White Russian, Valentina Pavlovna. Together they discovered the different roles played by mushrooms in the cultural histories of various peoples; in 1957 they published Mushrooms, Russia, and History, which reviewed the standing literature and brought to light a wealth of unpublished information. Much new information came from their trips to Mexico, where they studied what they called "ethnomycology." Extensive collaboration with R. Helm (Paris), a leading specialist on mushrooms of the world, resulted in several publications. Wasson was appointed an Honorary Research Associate and was Honorary Manager at the Garden. Only a few of his collections of fungi came to the Garden, but he contributed many publications on mushrooms to the Garden's Library.

Until recently the Garden did not have a lichenologist on staff, although specimens of lichens were obtained over the years by purchase, gift, and exchange. For example, many thousands of duplicate lichens from the herbarium of $\mathrm{W}$. A. Leighton (England) were received from Kew in 1904. Some 3000 lichen duplicates were received from the collection of $\mathrm{H}$. E. Hasse (California) in 1907. Beginning in 1979, Richard C. Harris has worked on the lichen collections, first as a volunteer, then as an Honorary Research Associate, and currently as Curatorial Assistant. His research interests include the lichens of eastern North America and the Neotropics. Since his arrival, the lichen collections have more than doubled in number. His own collections are being added to the herbarium.

Over the past decade or so, the Garden's collections of fungi have been enriched by donation 
of herbaria from various colleges and universities. Outstanding among these were $30,563 \mathrm{col}^{-}$ lections from the University of Massachusetts which include those of Margaret Barr Bigelow (Ascomycetes) and H. E. Bigelow (Basidiomycetes). Some 6479 collections were received from the A. O. Garrett herbarium at the University of Utah, 5498 from Wellesley College, 4993 from DePauw University, and 1116 from the University of Texas. Some 41,000 collections of fungi were received on exchange from the Carnegie Museum of Natural History, comprising material of all groups mostly from western Pennsylvania and surrounding areas. Important collections were the Hyphomycetes, studied by D. R. Sumstine, the earliest specialist on that group in North America. Also outstanding were the specimens of L. K. Henry, who made a lifetime study of the mycota of western Pennsylvania.

\section{Plant Pathologists}

Bernard O. Dodge (1872-1960; for a biography, see Robbins, 1962), a native of Wisconsin, became interested in botany as a youth on his father's farm and subsequently taught school in various towns in Wisconsin. He studied at the University of Wisconsin, where he met R. A. Harper, one of the great figures in American botany. When Harper moved to Columbia University, Dodge followed to do graduate work, obtaining his Ph.D. in Botany in 1912. Dodge had become interested in fungi that cause plant and animal diseases. In 1920 he was appointed Plant Pathologist (fruit diseases) with the U.S.D.A. in Washington, D.C. There, in addition to his work in plant pathology, he initiated his studies of Neurospora, a new genus described by Shear and Dodge. (His contributions in Neurospora genetics are discussed below, under "Experimental Mycologists.") By 1928 the Garden had decided that it required a plant pathologist to maintain the health of its living collections, and Dodge became its first plant pathologist (19281947). For about 20 years, he was the person responsible for the practical control of plant diseases and insect pests at the Garden, was consultant in mycology for local hospitals, universities, and such, and pursued research in plant pathology and in cytology and genetics of fungi. In cooperation with $\mathrm{H}$. W. Rickett (Bibliogra- pher at the Garden) he published a text on diseases of ornamental plants.

Between 1912 and 1957, Dodge authored and co-authored 163 papers: 78 papers on plant pathogenic fungi, 36 on Neurospora, 24 on the morphology and genetics of other fungi, 14 on the taxonomy of fungi, 8 reviews, and 2 biographies. He was the fourth President of the Mycological Society of America in 1935.

P. P. Pirone followed Dodge as plant pathologist (1948-1974). He obtained his Ph.D. at Cornell University. Before joining the Garden staff he studied diseases of ornamental plants at Rutgers University. He continued this interest at the Garden. He examined and isolated fungi from unhealthy plants and often inoculated healthy plants under controlled conditions, to determine whether it was the isolated fungus causing the disease. In addition to studying and applying control measures for the living collections at the Garden, he was consultant on plant disease and insect problems for sister institutions, universities, colleges, and such in the New York City area. The sixth edition of his book Tree Maintenance was published in 1988. He also revised and updated Diseases and Pests of Ornamental Plants (fourth edition), the successor to the Dodge and Rickett book on the same subject.

\section{Experimental Mycologists}

Beginning in 1927, at every opportunity in conversations, lectures, and publications, B. $O$. Dodge extolled the fundamental research possibilities in biological, cytological, and genetic studies with species of Neurospora. He carried out the first tetrad analysis with $N$. crass $a$ and showed that mating type segregated $4: 4$ in individual asci. He used sexual compatibility as a criterion in species recognition. He also demonstrated "pseudohomothallic" behavior in $N$. tetrasperma. He indicated that fungi, in their reproduction and inheritance, follow the same laws that govern these activities in higher plants and in animals. He clearly pointed out that ascospores are analogous to germ cells and thus have advantages for genetic analysis. He also determined that, because gametes in Neurospora are derived from a single mother cell, the exact relationship of all 8 ascospores in an ascus is known. G. W. Beadle and E. L. Tatum, geneticists at Stanford University who came under the 
spell of Dodge's enthusiasm for Neurospora, began to investigate and virtually founded the science of biochemical genetics. They acknowledged that Dodge did the basic work on morphology, taxonomy, and laboratory culture techniques for species of Neurospora and this became a key in the study of heredity that led to their Nobel Prize-winning work. They further acknowledged that without Dodge and his vision, insight and imagination, biochemical genetics via work with Neurospora would not have begun when it did. (For a review of Neurospora and its relationship to molecular biology, see Perkins, 1992.)

When William J. Robbins (1890-1978), a plant physiologist, came to the Garden as Director (1937-1958), he soon established a laboratory to do biochemical and physiological research on plant-growth regulators, tissue culture, and antibiotic production by fungi. After the discovery of the antibiotic penicillin from a fungus (Penicillium sp.) a flurry of activity occurred in the search for other antibiotics. Robbins, noting that few Basidiomycetes were being surveyed for antibiotic potential, began a search for and accumulation of living cultures of Basidiomycetes from around the world. More than $400 \mathrm{cul}-$ tures ( 300 of wood-destroying fungi) were tested for inhibition of several pathogenic bacteria, about one-half of which exhibited antibacterial activity.

Annette Hochberg Hervey (1920-1980) obtained her Ph.D. at the joint Columbia University-New York Botanical Garden graduate program, then joined the Garden's staff as Research Associate (1951-1980) to work with Dr. Robbins in the testing of the fungous cultures against bacteria. Most of the cultures consisted of sterile mycelium; after the antibiotic testing was done, experiments were carried out to determine what physiological conditions were needed to get spore production from the isolates. Another series of experiments endeavored to induce fruiting in the morel mushroom from mycelium and/ or solitary ascospore isolates. Much fundamental information on the environmental effects, need for vitamins, and production of hormones was obtained.

Hervey, her assistant Ina Leong, and C. T. Rogerson, collaborated with N. A. Weber of Swarthmore College in efforts to obtain fruiting of the "ant fungi," sterile basidiomycetous fungi cultivated as food by a largely tropical group of leaf-cutting ants. Some 36 strains were studied; four of these produced fruiting bodies of the mushroom genus Leucocoprinus.

Alma Whiffin Barksdale (1916-1981; for a biography, see Olive, 1982), a native of New Jersey, earned her Ph.D. at the University of North Carolina (1947) working with water molds (Oomycetes). From 1943 to 1952 she was a professional mycologist with the Upjohn Company in Michigan. In the mid-1940s she obtained from a species of Streptomyces an antifungal agent, cycloheximide (actidione), which is used in experiments involving genes and protein synthesis. It proved to be an important tool in treatment of human mycoses. In 1955 she joined the Garden staff as Research Associate and became Senior Research Associate (19611981); her research was funded by the NIH. Her primary work at the Garden centered on the taxonomy and sex-hormone system of water molds (primarily Achlya spp.). After ten years' work, and from hundreds of gallons of water in which a female strain of $A$. bisexualis had been grown, hormone A (now called antheridiol) was obtained in pure crystalline form. It is a steroid and is related to sex hormones of many other organisms, including human beings. In the 1960s Barksdale and Eva Sansome, in England, published cytological evidence that meiosis in Achlya occurs in the sex organs and that these organisms actually have diploid thalli. This contradicted the belief, held for about 100 years, that meiosis and recombination in the water molds occur in the germinating spores. Alma Barksdale published 35 scientific papers, alone and with colleagues.

Marjorie Anchel, a plant biochemist with NIH support, joined the staff to determine chemical makeup of fungal products, including pigments. She was, respectively, Research Associate (1947-1961), Senior Research Associate (19631971), Senior Chemist, and Administrator of the Laboratory (1973-1977). Early in the research, fungal polyacetylenes were discovered; several of these were purified and their structures were determined. The orange pigment produced by the mushroom Clitocybe illudens and the red pigment produced by the polypore Fomes juniperinus also were analyzed. Several biochemists, including T. C. McMorris and M. S. R. Nair, who specialized in the chemistry of plant products, became associated with the research program. Susan (Canham) Carey, a mycologist who 
TABle I

Postgraduate students of The New York Botanical Garden

\begin{tabular}{|c|c|c|c|c|c|}
\hline Student & Advisor & School & Degree, year & Subject & Thesis title \\
\hline Annette Hochberg Hervey & W. J. Robbins & Columbia & Ph.D., 1951 & Microbiology & $\begin{array}{l}\text { A survey of some Basidiomycetes for an- } \\
\text { tibacterial activity }\end{array}$ \\
\hline Susan T. (Canham) Carey & C. T. Rogerson & Columbia & Ph.D., 1966 & Mycology & $\begin{array}{l}\text { Taxonomy and morphology of } H y p o- \\
\text { crea citrina (Ascomycetes, Hypocre- } \\
\text { ales) }\end{array}$ \\
\hline Anna F. Doyle & C. T. Rogerson & Columbia & Ph.D., 1970 & Mycology & $\begin{array}{l}\text { A preliminary chemosystematic investi- } \\
\text { gation of the genus Nectria (Asco- } \\
\text { mycetes, Hypocreales) }\end{array}$ \\
\hline Gary J. Samuels & C. T. Rogerson & Columbia & Ph.D., 1971 & Mycology & $\begin{array}{l}\text { The taxonomic position of the genus } \\
\text { Nectriopsis (Ascomycetes, Hypocre- } \\
\text { ales) }\end{array}$ \\
\hline S. E. Carpenter & K. P. Dumont & CUNY & Ph.D., 1980 & Mycology & $\begin{array}{l}\text { Monograph of Crocicreas (Ascomy- } \\
\text { cetes, Helotiales, Leotiaceae) }\end{array}$ \\
\hline Rosalind Lowen & K. P. Dumont & CUNY & M.Sc., 1987 & Mycology & $\begin{array}{l}\text { A study of the genus Calycellina (Dis- } \\
\text { comycetes) }\end{array}$ \\
\hline Lois Brako & R. C. Harris & CUNY & Ph.D., 1987 & Lichenology & $\begin{array}{l}\text { The lichen genus Phyllopsora (Bacidi- } \\
\text { aceae) in the Neotropics }\end{array}$ \\
\hline Rosalind Lowen & C. T. Rogerson & CUNY & Ph.D., 1991 & Mycology & $\begin{array}{l}\text { A monograph of the genera Nectriella } \\
\text { and Pronectria }\end{array}$ \\
\hline Katia F. Rodrigues & G. J. Samuels & CUNY & Ph.D., 1992 & Mycology & $\begin{array}{l}\text { Endophytic fungi in the tropical palm, } \\
\text { Euterpe oleracea }\end{array}$ \\
\hline Ana Esperanza Franco & R. E. Halling & CUNY & Ph.D., 1994 & Mycology & $\begin{array}{l}\text { The genus Lepiota sensu stricto, with } \\
\text { observations on related taxa found in } \\
\text { Colombia }\end{array}$ \\
\hline
\end{tabular}

earned her Ph.D. in the joint Columbia University-New York Botanical Garden program, obtained NIH support for isolation and study of natural products from Ascomycetes.

\section{Academic Links and Education}

Almost from the beginning, the Garden was associated with Columbia University, either with individual faculty members held in common or, later, with the joint graduate program. At the turn of the century, Murrill, who was then a teacher at DeWitt Clinton High School in New York City, impressed L. M. Underwood, a Professor of Botany at Columbia who encouraged and facilitated Murrill's interest in fleshy fungi. In 1906 Seaver was given a leave of absence from his position as Instructor in Biology at Iowa Wesleyan College to take a fellowship at Columbia University. This fellowship enabled him to work in the herbarium of the Garden and, no doubt, to interact both with Underwood at Columbia and with Murrill at the Garden. From 1909 to 1920, Dodge was an assistant and then Instructor in Botany at Columbia University, earning his Ph.D. there in 1912. While he was on the staff of the Garden, he encouraged the renowned Drosophila geneticist T. H. Morgan, then at Columbia University, to use Neurospora.

Dodge's immersion in Neurospora genetics at the Garden stimulated Lindsay Olive, who joined the faculty of Columbia University in 1949, to study genetic segregation in Neurospora. Over a period of about 12 years, from the late 1950 s, Olive and his postdoctoral students published several important papers on the genetics of Neurospora. Rogerson was a frequent, informal advisor to Ronald H. Petersen while the latter was undertaking his Ph.D. research in aquatic Hyphomycetes with Olive. Rogerson and Petersen undertook joint collecting trips to the Smoky Mountains in 1961 and 1962, and Rogerson encouraged Petersen to take up a "second career" by specializing in taxonomy of the Clavariaceae.

Another aspect of the association between The New York Botanical Garden and Columbia University was that staff members of the Garden also held adjunct status in the Graduate School at Columbia. Before the suspension of that program in 1971, four students obtained doctorates under the direction of Garden staff members. Since 1971 , a similar arrangement has existed with the City University of New York at Lehman College. Of the nine students who have so far obtained a doctorate through the Garden (Table I), five are still active in mycology. Rosalind Lowen is a Research Associate at the Garden, where she collaborates with Rogerson on sys- 
tematics of the Hypocreales. Steven E. Carpenter is employed by the firm of Hewlett-Packard and also operates a mycological diagnostic service in Oregon. Ana Esperanza Franco is currently teaching at the Universidad de Antioquia in Colombia. Katia F. Rodrigues is director of mycology at the Instituto Oswaldo Cruz in Rio de Janeiro, Brazil. Gary J. Samuels is a mycologist with the U.S. National Fungus Collections in Beltsville.

\section{Summary}

Since its inception more than 100 years ago, The New York Botanical Garden has been among the most important international centers of mycological research. During those 100 years, eight taxonomically oriented mycologists were employed as curators, and for 36 years two taxonomic mycologists have simultaneously been on staff. There has never been a time when the Garden's mycologists have not significantly influenced mycological thinking. This influence has been felt in exploration, floristics, systematics, nomenclature, and experimental mycology. The Garden's mycologists have always held key positions in the American and international mycological communities. As we write this review, though, all traditional field-oriented sciences such as mycology are under attack and the number of mycologists is declining. The herbarium and library are resources that have developed over the past 100 years. The Garden has the second largest collection of fungi in the Americas, comprising, as of 30 June 1995, a total of 589,501 specimens, among which are 479,354 fungi and 110,147 lichens. The challenge for The New York Botanical Garden is great. It is essential that these irreplaceable re- sources be maintained and that the traditionally strong mycology program be supported so that it can continue making major contributions to our knowledge of the Earth's biological diversity.

\section{Acknowledgments}

Most of the historical material for this review can be found in Journal of The New York Botanical Garden, Mycologia, Bulletin of the Torrey Botanical Club, Torreya, and Brittonia. Some information came from unpublished reports of staff members deposited in the Library of the Garden or in the Cryptogamic Herbarium files. A Brief History of Mycology in North America, published by D. P. Rogers (Second International Mycological Congress, 1977) was also very helpful.

\section{Literature Cited}

Barnhart, J. H. 1941. Howard James Banker (18661940). Mycologia 33: 341-343.

Bonar, L. 1956. Elizabeth Eaton Morse. Mycologia 48: 439-442.

Chardon, C. E. 1929. Franklin Sumner Earle. Mycologia 21: 301-303.

Gilkey, H. M. 1949. Sanford Myron Zeller. Mycologia 41: 357-368.

Hagelstein, R. 1944. William Codman Sturgis. Mycologia 36: 123-124.

Olive L. S. 1982. Alma Whiffin Barksdale, 19161981. Mycologia 74: 359-362.

Perkins, D. D. 1992. Neurospora: the organism behind the molecular revolution. Genetics 130: 687-701.

Robbins, W. J. 1962. Bernard Ogilvie Dodge, 18721960. Biogr. Mem. Natl. Acad. Sci. 36: 85-124.

Rogerson, C. T. 1973. Fred Jay Seaver. Mycologia 65: $721-724$.

Seaver, F. J. 1953. Gertrude Simmons Burlingham. Mycologia 45: 136-138.

Weber, G. F. 1961. William Alfonso Murrill. Mycologia 53: 543-557. 